\title{
Response of cut rose cv. cardinal to sucrose and $\mathrm{NaOCl}$ concentration
}

\author{
Malik Owais Ullah Awan ${ }^{1}$, Nangial Khan ${ }^{2 *}$, Murad Ali ${ }^{1}$, Muhammad \\ Junaid $^{2}$, Sohail ${ }^{3}$, Farooq Nawaz ${ }^{2}$, Rayyan Khan ${ }^{2}$, Junaid Ali Shah ${ }^{3}$, \\ Akhtar Ali ${ }^{2}$, Nasir Mehmood ${ }^{4}$, Zia Ullah ${ }^{3}$, Irshad Ahmad ${ }^{3}$ and Anis Ur \\ Rehman Khalil ${ }^{3}$ \\ 1. Department of Horticulture, The University of Agriculture Peshawar-Pakistan \\ 2. Department of Agronomy, The University of Agriculture Peshawar-Pakistan \\ 3. Department of Water management, The University of Agriculture Peshawar-Pakistan \\ 4. Department of Crop Protection, The University of Agriculture Peshawar-Pakistan \\ *Corresponding author's email: nangialkhan@ hotmail.com
}

Citation

Malik Owais Ullah Awan, Nangial Khan, Murad Ali, Muhammad Junaid, Sohail, Farooq Nawaz, Rayyan Khan, Junaid Ali Shah, Akhtar Ali, Nasir Mehmood, Zia Ullah, Irshad Ahmad and Anis Ur Rehman Khalil. Response of cut rose cv. cardinal to sucrose and $\mathrm{NaOCl}$ concentration. Pure and Applied Biology. Vol. 6, Issue 1, pp171-179. http://dx.doi.org/10.19045/bspab.2017.60011

Received: $30 / 08 / 2016$

Revised: 30/11/2016

Accepted: 24/12/2016

Online First: 02/02/2017

\section{Abstract}

To find the response of cut rose $\mathrm{cv}$. Cardinal to sucrose and $\mathrm{NaOCl}$ concentration, an experiment was conducted with normal day light under room condition and natural ventilation. Completely Randomized Design (CRD) was used for the experiment by replicating 3 times. Solutions of different combination of Sucrose levels of $0,4,8$ and $12 \%$ and sodium hypochlorite with 0 (control), 5, 10 and $15 \mathrm{mgL}^{-1}$ concentrations were applied to the cut rose cv. Cardinal. By analyzing of data collected, illustrated that cut rose cv. Cardinal significantly responded to sucrose and $\mathrm{NaOCl}$ levels. Combination of $15 \mathrm{mgl}^{-1} \mathrm{NaOCl}$ with $12 \%$ sucrose was found more favorable for the whole studied parameters. Early flower opening (4 days), maximum flower fresh weight (12.30g), flower size (6.01 $\mathrm{cm}$ ), maximum flower longevity (16 days) and dry weight (3.78) were observed for cut rose retained in solution mixture of $12 \%$ sucrose and $15 \mathrm{mgL}^{-1} \mathrm{NaOCl}$. The solution containing $12 \%$ Sucrose and $15 \mathrm{mgL}^{-1} \mathrm{NaOCl}$ significantly increased $(12.30 \mathrm{~g})$ flower fresh weight. Less percent petal drop (10\%) was observed by solution containing combination of $12 \%$ sucrose and $15 \mathrm{mgL}^{-1} \mathrm{NaOCl}$ as compared to control $(33.80 \%)$. As for sugar application individually on cut rose, early flower opening took place (4 days), maximum flower size $(6.14 \mathrm{~cm})$, flower fresh weight $(11.57 \mathrm{~g})$, minimum flower wilting $(15.58 \%)$, maximum flower dry weight $(3.78 \mathrm{~g})$, minimum petal drop $(23.96 \%)$ and longer vase life (3.39 days) were observed for $12 \%$ sugar solution. For $\mathrm{NaOCl}$ application individualy, the cut rose showed early flower opening took place (4 days), maximum flower size $(6.16 \mathrm{~cm})$, maximum flower fresh weight $(11.27 \mathrm{~g})$, minimum flower wilting $(15 \%)$, maximum dry weight $(4.13$ g), minimum petal drop (18.75\%) and longer vase life (14.77) were observed for $15 \mathrm{mg}^{-1} \mathrm{l}^{1}$ of $\mathrm{NaOCl}$ solution In general, $15 \mathrm{mg} . \mathrm{l}^{-1} \mathrm{NaOCl}$ and $12 \%$ sucrose is considered a best solution combination to be used for cut rose flowers cv. cardinal longer and quality vase life.

Keywords: Cut Rose; Sucrose; $\mathrm{NaOCl}$ 


\section{Introduction}

The significance of cut flower production globally increased after World War II due to improvement in the cut flower production. Cut flower production invented new technologies and techniques from production to utilization of cut flower. Floriculture is contributing as an important segment in agricultural businesses in several countries of the world. Cut flower trade recorded internationally $25 \%$ annual growth. Cut flower contributing $60 \%$ of the world international floriculture trade which is 11 billion dollar annually. The international trades amplified ten times from 0.5 billion in 1990 to 5.1 billion in 2005 and estimated to twofold up to 2025 [1].

Rose cut flower cultivation is gaining popularity among the farmers in Pakistan is increasing due to its reasonable price [2]. Allah (S.W.T) has gifted a wide range of climatic conditions to Pakistan providing opportunity to grow different species of cut flowers, which can improve the economic status of the growers. The local demand and consumption have not yet satisfied due mega difference between supply and demand [3]. Many areas of Khyber Pakhtunkhwa are appropriate for growing of rose flowers. Natural growth of Daffodil and Narcissus in Swat and Abbottabad provides opportunity for cut rose trade in the Province due increase in demand of Daffodils and Narcissus across the country. The farmers in the mountain areas have started growing these flowers in their agriculture lands [4].

Rosa hybrida is a member of roseaceae family and Genus Rosa which containing more than 150 species and 1000 cultivars. Rose is grown-up for amazing beauty of their flowers. Rose plant is used as specimen plant, as hedges, in the border, and as creeper for training on pillars and walls [5].

Rose having superiority over other flowers due to frequent used for decoration purposes. The role of rose in manufacturing of medicine cannot be denied. Similarly, rose also having an important ingredient in many foods products of nutritional value [6]. Rose flowers are often harvested in commercial maturity or bud stage and so flowers need large amount of soluble carbohydrates for opening. Treatment with sucrose promoted unfolding of petals, inhibited the decrease in fresh weight and occurrence of petals of cut rose [7].

Usually cut flowers have a short vase life. The vase life of cut flowers can be prolonged by use of environmental conditions, sucrose solution, sodium hypochlorite and silver thiosulphate solution [8]. To avoid wilting of flowers, they are dipped in water. However, a risk of air embolism occurs when cutting the flowers during harvesting. Air is usually absorbed by the stem and this bubble of air prevents water uptake. To avoid this problem the stem is re-cut in water mixed with citric acid [9].

Sodium hypochlorite as a source of chlorine is a cheap, environment friendly agent that can be used in the vase-solutions. Chlorine is used to inhibit growth of bacteria and fungi in cut flower vase solutions. Calcium hypochlorite, Sodium hypochlorite and dichloroisocyanuric acid (DICA) are the source for chlorination. During Chlorination following equilibrium reaction takes place. $\mathrm{Cl}_{2}+\mathrm{OH}^{-} \leftrightarrow \mathrm{HOCl}+\mathrm{OCl}^{-}+\mathrm{H}^{+}$. $\mathrm{HOCl}$ is the effective form of chlorine [10].

Cut flowers need to last longer in a vase or flower arrangement with their visual qualities, scent and look maintained in order to get consumer's acceptance. Cut flower visual quality and petals turgor can remain acceptable for only two or three days under normal conditions. Since most of the people would like to enjoy the beauty and smell of flowers for a longer period of time. Pakistan as an agriculture country can find a great space in international market by adopting cut flower production as industry. Similarly 
the cut rose production having a future scope in the province KP. The preservatives price used in this experiment are cheap so any one can use it. The socioeconomic value of roses and its esteem as a cut flower give among the people compel us to explore the potential of extending vase life by using various preservatives.

\section{Materials and method}

The experiment "response of cut rose cv. Cardinal to sucrose and $\mathrm{NaOCl}$ concentration" was performed at the Postharvest Laboratory, Department of Horticulture in The University of Agriculture, Peshawar during the Feb, 2014 aimed to observe the impact of $\mathrm{NaOCl}$ and sucrose on vase life at normal room temperature and natural ventilation.

Cut rose (Rosa hybrida. cv. cardinal) flowers were took from Sarhad Nursery Farm, Tarnab Farm Peshawar. Flowers harvested at the morning in loose bud stage by giving a slant cut having $20 \mathrm{~cm}$ stalk and immersed it in buckets containing simple water in upright position. Before transportation to the lab, cut rose was placed in Shade covered with plastic minimize moisture loss. At the laboratory, the stems

\section{Treatment combination}

A0B0

A1 B0

A2 B0

A3 B0

\section{Parameters that were studied}

Each of these treatments of different combinations was applied to a vase solution sample of five flowers. The parameters studied during the experiment were as follows.

\section{Flower opening (days)}

Flower opening (days) were calculated for each treatment from initial time when flowers were placed in the vase solution. The flowers were counted as open when were re-cut by giving a slant cut, removing 5 $\mathrm{cm}$, and the stem length was kept $15 \mathrm{~cm}$ in order to remove air emboli to prevent blockage of xylem vessels due to air bubbles accumulation.

\section{Preparation of $\mathrm{NaOCl}$}

Different concentration of $\mathrm{NaOCl}$ solutions were prepared by taking the required amount on $\mathrm{NaOCl}$ in beaker and filled it with distilled water up to 1 liter.

$\begin{array}{ll}\text { Factor A } & \text { NaOCl levels } \\ & \text { A0 }=0 \mathrm{mg} . \mathrm{L}^{-1} \\ & \text { A1 }=5 \mathrm{mg} . \mathrm{L}^{-1} \\ & \text { A2 }=10 \mathrm{mg} . \mathrm{L}^{-1} \\ & \text { A3 }=15 \mathrm{mg} . \mathrm{L}^{-1}\end{array}$

\section{Preparation of Sucrose solution}

Solution of sucrose was prepared by dissolving different amount of sucrose in 100 $\mathrm{ml}$ of distilled water in a beaker. For the required solution $0,40,80$ and $120 \mathrm{~g}$ of sucrose was dissolved in $100 \mathrm{ml}$ of distilled water in order to prepare $0,4,8$, and $12 \%$ w/v solution respectively.

\begin{tabular}{|c|c|}
\hline Factor B & $\begin{array}{c}\text { Sucrose levels } \\
\text { B0 }=0 \% \mathrm{w} / \mathrm{v} \\
\mathrm{B} 1=4 \% \mathrm{w} / \mathrm{v} \\
\mathrm{B} 2=8 \% \mathrm{w} / \mathrm{v} \\
\mathrm{B} 3=12 \% \mathrm{w} / \mathrm{v}\end{array}$ \\
\hline
\end{tabular}

A0B2

A0B3

A1 B2

A1 B3

A2 B2

A2 B3

A3 B2 sepal of the flower unfolded and anther were seen clearly.

Flower size (cm)

Flowers sizes were calculated with help of verneir caliper when all the petal of the flower fully open

\section{Flower fresh weight (g)}

When flower attain its maximum size, flower fresh weight was calculated with the help of electronic balance. 


\section{Petal drop (\%)}

Petal drop percentage was found by counting total petals of each treatment and dropped petal and then using the given formula.

Petal drop $(\%)=\quad$ No. of dropped petal $\times 100$

Vase life (days)

Total No. petal

Vase life of flower is termed as detaching flower from its plant until its possession of decorative value. Vase life (days) were calculated by given formula.

Vase life (days) $=$ Day when cut rose was placed in solution to day when flower loss decorative value

\section{Flower dry weight (g)}

Flower dry weight in grams was calculated when flowers of the each sample were fully dried with help of balance and data was noted.

\section{Statistical method}

\section{Statistical analysis}

During data analysis CRD model by applying least significance Difference Test. The detail of treatments is given as under.

\section{Results and discussion}

To study the response of cut rose CV. Cardinal to sucrose and $\mathrm{NaOCl}$, an experiment was carried out at Post harvest laboratory, The University of Agriculture, Peshawar in February 2014.

\section{Flower opening}

The data for average flower opening (days) is given in Table 1 . The mean data clearly show that late flower opening (5.16) days were recorded for flower supplied with 0 $\mathrm{mgL}^{-1}$ sodium hypochlorite, followed by average flower opening (5.01) days for $\mathrm{NaOCl}$ at $5 \mathrm{mg} . \mathrm{L}^{-1}$ while early flower opening (4.32) days were recorded by flower interacted with $15 \mathrm{mg} . \mathrm{L}^{-1} \mathrm{NaOCl}$ solution. The data for sucrose solution showed that $8 \%$ Sucrose Solution resulted early flower opening (4.27) days, followed by flower opening (4.71) days for $4 \%$ sucrose solution while late flower opening (5.23) days were obtained from flower supplied with distilled water i.e. control treatment.

Quality retention of cut roses are kept due to carbohydrate and soluble sucrose in the petals for extended period. So the flower sample applied with sucrose and $\mathrm{NaOCl}$ was found significant. Due to $\mathrm{NaOCl}$ the $\mathrm{pH}$ of the solution in vase became lower which prevent bacterial growth which to prevent vessel blockage thus advance the uptake of water by cut rose flower stem. These Results are in conformity with Liao et al. [6] which resulted that application $\mathrm{NaOCl}$ at $15 \mathrm{mg}^{-1}$ and sucrose at $40 \mathrm{~g}$ helped to open the cut rose flowers early.

Table 1. Flower opening (days) of cut rose as influenced by different concentration of sucrose and $\mathrm{NaOCl}$ concentration

\begin{tabular}{|c|c|c|c|c|c|}
\hline \multirow[t]{2}{*}{ Sucrose levels (\%) } & \multicolumn{4}{|c|}{ NaOCl levels (mg.L $\left.\mathrm{L}^{-1}\right)$} & \multirow[t]{2}{*}{ Mean } \\
\hline & 0 & 5 & 10 & 15 & \\
\hline 0 & 4.71 & 3.86 & 4.90 & 5.40 & $5.23 \mathrm{a}$ \\
\hline 4 & 3.82 & 3.83 & 4.70 & 4.74 & $4.71 \mathrm{ab}$ \\
\hline 8 & 4.35 & 4.58 & 4.90 & 5.02 & $4.27 \mathrm{~b}$ \\
\hline 12 & 4.91 & 5.00 & 5.52 & 5.48 & $4.72 \mathrm{ab}$ \\
\hline Mean & $5.16 \mathrm{a}$ & $5.01 \mathrm{a}$ & $4.32 \mathrm{~b}$ & $4.45 b$ & \\
\hline
\end{tabular}

LSD at $\alpha 0.05$ for $\mathrm{NaOCl}$ and Sucrose level $=0.55$

\section{Flower size}

The data for flower size is shown in Table 2. The mean data clearly show that larger flower size $(6.16 \mathrm{~cm})$ was noted for flower supplied with $15 \mathrm{mg} \cdot \mathrm{L}^{-1}$ sodium hypochlorite, followed by average flower size $(5.94 \mathrm{~cm})$ for $\mathrm{NaOCl}$ at $10 \mathrm{mg} . \mathrm{L}^{-1}$ while small size flower $(5.52 \mathrm{~cm})$ were obtained by flower 
interacted with $\mathrm{NaOCl}$ at $0 \mathrm{mg} \cdot \mathrm{L}^{-1}$. The data for sucrose solution showed that $12 \%$ sucrose solution produced maximum size flowers $(6.14 \mathrm{~cm})$, followed by flower size $(5.77 \mathrm{~cm})$ for $8 \%$ sucrose solution and smaller flower size $(5.47 \mathrm{~cm})$ were obtained from flower supplied with distilled water i.e. control treatment. The application of sucrose and sodium hypochlorite showed significance increase in size of cut rose flower. Finding showed that sucrose has increased the size cut rose flowers life [11, 12]. Sodium hypochlorite postpones any formation of microorganism colonies in stem xylems due to the effects of antimicrobe properties. Therefore it may also cause an increase in water absorption and also increasing of flower diameter.

Table 2. Flower size $(\mathrm{cm})$ of cut rose flower as influenced by different concentration of $\mathrm{NaOCl}$ and Sucrose

\begin{tabular}{|l|l|l|l|l|l|}
\hline \multirow{2}{*}{$\begin{array}{l}\text { Sucrose levels } \\
(\%)\end{array}$} & \multicolumn{4}{|c|}{ NaOCl levels $\left(\mathbf{m g L}^{-1}\right)$} & \multirow{2}{*}{ Mean } \\
\cline { 2 - 6 } & 0 & 5 & 10 & 15 & \\
\hline 0 & 6.04 & 6.20 & 6.00 & 6.30 & $5.47 \mathrm{a}$ \\
\hline 4 & 5.10 & 5.25 & 5.72 & 5.80 & $5.77 \mathrm{~b}$ \\
\hline 2 & 5.23 & 5.86 & 5.88 & 6.09 & $5.97 \mathrm{a}$ \\
\hline 3 & 5.72 & 5.55 & 6.14 & 6.47 & $6.14 \mathrm{a}$ \\
\hline Mean & $5.52 \mathrm{~b}$ & $5.72 \mathrm{~b}$ & $5.94 \mathrm{ab}$ & $6.16 \mathrm{a}$ & \\
\hline
\end{tabular}

LSD at $\alpha 0.05$ for $\mathrm{NaOCl}$ and Sucrose level $=0.44$

\section{Fresh Weight}

The data for average flower fresh weight is given in Table 3. The mean data clearly show that extreme flower fresh weight $(11.27 \mathrm{~g})$ were noted for flower supplied with $15 \mathrm{mg} . \mathrm{L}^{-1}$ sodium hypochlorite, followed by average flower fresh weight $(10.74 \mathrm{~g})$ for $\mathrm{NaOCl}$ at $10 \mathrm{mg} . \mathrm{L}^{-1}$ while least flower fresh weight (10.44) were obtained by flower interacted with control i.e 0mg.L${ }^{1} \mathrm{NaOCl}$. The data for sucrose solution showed that $12 \%$ Sucrose Solution produced maximum flowers fresh weight $(11.27 \mathrm{~g})$, followed by flower fresh weight $(10.81 \mathrm{~g})$ for $8 \%$ while minimum flower fresh weight(10.14 g)were obtained from flower supplied with distilled water i.e control treatment.

Decorative plants like rose flower is also responsive to increasing of bacteria amount in liquid. In case of bacteria concentration in flower vase liquid has a scope of 107-108 $\mathrm{ml}$, it may cause a reduction in water absorption. In a colony of $3 \times 10 \mathrm{ml}$ first signs of wilted after one hour was witnessed
[13]. Carbohydrates are responsible for controlling of structure and mitochondria, water balance and any transfers in plant. Any applying of water free from any microbes, reducing acidity of maintenance liquid, anti-microbes, re-cut of the stem at the time of putting it inside the liquid may cause better absorption of water. Higher water uptake and development of corolla are the properties concerned with increase in Fresh weight. While consumption of available carbohydrate in respiration causes decrease in fresh weight. The rate of Respiration is enhanced by ethylene manufacture in the senescing tissues. So improving in quality and increase in vase life of cut rose and increase in fresh weight is due to the supply of carbohydrates by sucrose for respiration process. While, $\mathrm{NaOCl}$ act as ethylene inhibitor which resulted increase in fresh weight [14]. Sucrose and $\mathrm{NaOCl}$ combination is best for increase of flower weight than other chemicals 
Table 3. Fresh weight of cut rose flower as influenced by different concentration of Sucrose and $\mathrm{NaOCl}$

\begin{tabular}{|c|c|c|c|c|c|}
\hline \multirow{2}{*}{$\begin{array}{l}\text { Sucrose levels } \\
(\%)\end{array}$} & \multicolumn{4}{|c|}{ NaOCl levels (mg.L ${ }^{-1}$ ) } & \multirow[t]{2}{*}{ Mean } \\
\hline & 0 & 5 & 10 & 15 & \\
\hline 0 & 9.63 & 10.10 & 10.25 & 10.59 & $10.14 \mathrm{c}$ \\
\hline 1 & 10.12 & 10.06 & 10.74 & 11.24 & $10.54 \mathrm{~b}$ \\
\hline 2 & 10.60 & 11.11 & 10.58 & 10.94 & $10.81 \mathrm{~b}$ \\
\hline 3 & 11.43 & 11.18 & 11.37 & 12.30 & $11.57 \mathrm{a}$ \\
\hline Mean & $10.44 \mathrm{~b}$ & $10.61 \mathrm{~b}$ & $10.74 \mathrm{~b}$ & $11.27 \mathrm{a}$ & \\
\hline
\end{tabular}

LSD at $\alpha 0.05$ for $\mathrm{NaOCl}$ and Sucrose level $=0.33$

Flower wilting (\%)

The data for average flower wilting $(\%)$ is given in Table 4 . The mean data clearly show that least flower wilting (15\%) was recorded for flower supplied with $15 \mathrm{mg} . \mathrm{L}^{-1}$ sodium hypochlorite, followed by average flower wilting $(17.50 \%)$ for $\mathrm{NaOCl}$ at 10 $\mathrm{mg} . \mathrm{L}^{-1}$ while greater flower wilting $(34.17 \%)$ were obtained by flower interacted with control. The data for sucrose solution showed that $12 \%$ Sucrose Solution showed minimum flower wilting (15.58\%), followed by flower wilting $(21.92 \%)$ for $8 \%$ while maximum flower wiling $(33.42 \%)$ were obtained from flower supplied with distilled water i.e control treatment.

The property of less wilting percentage of flowers leads to longer vase life, therefore it is considered better as compared to more wilting. $\mathrm{NaOCl}$ affords an acidic medium which avoids pathogenic growth at vascular tissues which enable flower to sufficient water uptake Carbohydrate source improve vase life and quality of flower by imminent carbohydrate undernourishment. So $\mathrm{NaOCl}$ causes inhibition blockage of vessels is and ethylene levels is kept same and causes improved vase life which results in flower fading $\%$ age decrease. Application of Sucrose and $\mathrm{NaOCl}$ resulted to minimize percent fading by falling chlorophyll content of the flower from consumption and carbohydrates conservation in petals [15]. $10 \%$ sucrose application and $\mathrm{NaOCl} 15 \mathrm{mg}$ stemmed in highest water uptake and lowest transpiration losses [14].

Table 4. \% flower wilting as influenced by different concentration of $\mathrm{NaOCl}$ and sucrose

\begin{tabular}{|c|c|c|c|c|c|}
\hline \multirow{2}{*}{$\begin{array}{c}\text { Sucrose } \\
\text { levels (\%) }\end{array}$} & \multicolumn{4}{|c|}{ NaOCl levels (mg.L-1) } & \multirow{2}{*}{ Mean } \\
\cline { 2 - 5 } & 0 & 5 & 10 & 15 & \\
\hline 0 & 54.67 & 39.00 & 20.00 & 20.00 & $33.42 \mathrm{a}$ \\
\hline 4 & 35.00 & 29.33 & 15.33 & 14.00 & $23.42 \mathrm{~b}$ \\
\hline 8 & 26.33 & 26.00 & 20.00 & 15.33 & $21.92 \mathrm{~b}$ \\
\hline 12 & 20.67 & 16.33 & 14.67 & 10.67 & $15.58 \mathrm{c}$ \\
\hline Mean & $34.17 \mathrm{a}$ & $27.67 \mathrm{~b}$ & $17.50 \mathrm{c}$ & $15.00 \mathrm{~d}$ & \\
\hline
\end{tabular}

LSD at $\alpha 0.05$ for $\mathrm{NaOCl}$ and Sucrose level $=2.23$

LSD at $\alpha 0.05$ for $\mathrm{NaOCl} \times$ Sucrose $=4.46$

\section{Dry Weight (g)}

The data for average flower dry weight is given in Table 5. The mean data clearly show that greater flower dry weight (4.13 g) was noted for flower supplied with $15 \mathrm{mg} . \mathrm{L}^{-1}$ sodium hypochlorite, followed by average flower dry weight (3.78 g) for $\mathrm{NaOCl}$ at $10 \mathrm{mg} . \mathrm{L}^{-1}$ while smaller flower dry weight $(2.91 \mathrm{~g})$ were obtained by flower interacted with control treatment. The data for sucrose solution showed that $12 \%$ Sucrose Solution resulted in maximum size 
flower dry weight (3.78g), followed by flower dry weight $(3.77 \mathrm{~g})$ for $8 \%$ sucrose solution while lowest flower dry weight (3.52g) were obtained from flower supplied with control treatment.

Until detachment of flower from plant, it gets if food from plant ant then starts to consumption of stored food on detachment.
Therefore cut rose requires nutrient for its vase life continuation. The role of sucrose is to act as substrate for maintaining turgidity and as nutrient subtrates. Cut rose flower placed in solution of $15 \mathrm{mg} . \mathrm{L}-1$ and $12 \%$ sucrose maintained fresh weights above initial weights even up to the $8^{\text {th }}$ day of vase life [16].

Table 5. Flower dry weight of cut rose as influenced by different concentration of Sucrose and $\mathrm{NaOCl}$

\begin{tabular}{|l|l|l|l|l|l|}
\hline \multirow{2}{*}{$\begin{array}{l}\text { Sucrose } \\
\text { levels }(\%)\end{array}$} & \multicolumn{4}{|c|}{ NaOCl levels (mg.L-1) } & Mean \\
\cline { 2 - 6 } & 0 & 5 & 10 & 15 & \\
\hline 0 & 2.69 & 3.24 & 3.47 & 3.61 & $3.25 \mathrm{c}$ \\
\hline 1 & 2.85 & 3.48 & 3.78 & 3.97 & $3.52 \mathrm{~b}$ \\
\hline 3 & 2.96 & 3.84 & 3.98 & 4.30 & $3.77 \mathrm{a}$ \\
\hline Mean & 3.15 & 3.43 & 3.90 & 4.62 & $3.78 \mathrm{a}$ \\
\hline
\end{tabular}

\section{Petal Drop (\%)}

The data for average petal drop (\%) is given in Table 6 . The mean data clearly show that least petal drop (18.75\%) was recorded for flower supplied with $10 \mathrm{mg} . \mathrm{L}^{-1}$ sodium hypochlorite, followed by average flower size $(26.04 \%)$ for $\mathrm{NaOCl}$ at $5 \mathrm{mg} . \mathrm{L}^{-1}$ while greater petal drop $(35.42 \%)$ were obtained by flower for control solution. The data for sucrose solution showed that $12 \%$ Sucrose Solution produced minimum petal drop $(23.96 \%)$, followed by petal drop $(25 \%)$ for $8 \%$ sucrose solution, while maximum petal drop (33.33\%), were obtained from flower supplied with distilled water i.e control

treatment.

Table 6. Flower petal drop (\%) influenced by different concentration of $\mathrm{NaOCl}$ and sucrose

\begin{tabular}{|c|c|c|c|c|c|}
\hline \multirow{2}{*}{$\begin{array}{l}\text { Sucrose levels } \\
(\%)\end{array}$} & \multicolumn{4}{|c|}{ NaOCl levels (mg.L $\left.{ }^{-1}\right)$} & \multirow[t]{2}{*}{ Mean } \\
\hline & 0 & 5 & 10 & 15 & \\
\hline 0 & 41.67 & 33.33 & 29.17 & 29.17 & $33.33 \mathrm{a}$ \\
\hline 4 & 37.50 & 29.17 & 16.67 & 20.83 & $26.04 \mathrm{~b}$ \\
\hline 8 & 33.33 & 20.83 & 16.67 & 29.17 & $25.00 \mathrm{~b}$ \\
\hline 12 & 29.17 & 20.83 & 12.50 & 33.33 & $23.96 \mathrm{~b}$ \\
\hline Mean & $35.42 \mathrm{a}$ & $26.04 \mathrm{~b}$ & $18.75 \mathrm{c}$ & $28.13 \mathrm{~b}$ & \\
\hline
\end{tabular}

LSD at $\alpha 0.05$ for $\mathrm{NaOCl}$ and Sucrose level $=6.19$
Ethylene production is main factor in Petal drop due to leaf abscission in cut flowers. Literature review showed that both sucrose and $\mathrm{NaOCL}$ proved to be useful in this regard as sucrose reduces chlorophyll content and preserves carbohydrate contents of cut roses. It can be understood that sucrose acts as anti-ethylene compound and thus prolonging vase life and leaf abscission. $\mathrm{NaOCl}$ is also an anti-ethylene in nature, thus limiting the activities of ethylene by application of sucrose and NaOCL, leaf abscission and petal drop can be reduced. $\mathrm{NaOCl}$ and sucrose resulted in longer vase life and reduced petal drop as compared to distilled water in cut rose flowers [14]. 


\section{Vase life (days)}

The data for average vase life of flower (days) size is given in Table 7 . The mean data clearly show that larger vase life of flower (14.77days) was recorded for flower supplied with $15 \quad \mathrm{mg} . \mathrm{L}^{-1}$ sodium hypochlorite, followed by vase life of flower ( 13.03 days) for $\mathrm{NaOCl}$ at $\mathrm{mg} . \mathrm{L}^{-1}$ while least vase life of flower ( 9.53days) were obtained by flower kept in control treatment. The data for sucrose solution showed that $12 \%$ Sucrose Solution resulted in vase life of flower (14.77 days), followed by vase life of flower (13.03 days) for $8 \%$ while minimum vase life of flower (9.53 days) were obtained from flower supplied with distilled water i.e control treatment.

The part of sucrose and $\mathrm{NaOCl}$ in the extension of cut rose flowers vase was studied during this research showed that effect of sucrose on the provision of substrates for respiration and other function for performing different processes, sodium hypochlorite, therefore lengthier cut rose flowers vase life was noted. This widely accepted role of sucrose as provider of additional substrates for respiration has perhaps largely over-shadowed other important roles.

Gray mold is caused by Botrytis cinerea., a fungal pathogen that causes in Rose, gerbera chrysanthemum and other cut flower species. Deposition of conidia on petals during flower development is infected in rose. $\mathrm{NaOCl}$ application of rose flowers more useful in reducing B. cinerea infection than many other fungicides [17]. Sucrose extended the vase life Heuchera sanguine Engelm flowers, Limonium, spray carnations [18]. Liatris spicata, sweet pea, Delphinium, Gentiana, snapdragon, Eustoma, rose and Oncidiu [19].

Table 7. Flower longevity (days) influenced by different concentration of $\mathrm{NaOCl}$ and Sucrose

\begin{tabular}{|l|l|l|l|l|l|}
\hline \multirow{2}{*}{$\begin{array}{l}\text { Sucrose levels } \\
(\%)\end{array}$} & \multicolumn{4}{|c|}{ NaOCl levels $\left(\mathbf{m g . L}^{-\mathbf{1}}\right)$} & \multirow{2}{*}{ Mean } \\
\cline { 2 - 6 } & 0 & 5 & 10 & 15 & \\
\hline 0 & 8.77 & 8.50 & 9.42 & 11.45 & $9.53 \mathrm{~d}$ \\
\hline 4 & 9.90 & 9.90 & 12.69 & 12.68 & $11.29 \mathrm{c}$ \\
\hline 8 & 10.91 & 12.33 & 13.50 & 16.03 & $13.19 \mathrm{~b}$ \\
\hline 12 & 12.41 & 15.79 & 16.48 & 18.93 & $15.90 \mathrm{a}$ \\
\hline Mean & $10.50 \mathrm{~d}$ & $11.63 \mathrm{c}$ & $13.03 \mathrm{~b}$ & $14.77 \mathrm{a}$ & \\
\hline
\end{tabular}

LSD at $\alpha 0.05$ for $\mathrm{NaOCl}$ and Sucrose level $=0.57$

LSD at $\alpha 0.05$ for $\mathrm{NaOCl} \times$ Sucrose $=1.13$

\section{Conclusions}

$12 \%$ of sucrose solution gave the best result regarding early flower opening, larger flower size, maximum flower fresh, dry weight, minimum percent petal drop and wilting and longer vase life. $15 \mathrm{mgl}^{-1}$ solution gave the best result regarding early flower opening, larger flower size, maximum flower fresh and dry weight, minimum percent petal drop and wilting and longer vase life. The interaction of sucrose and $\mathrm{NaOCl}$ at $12 \%$ sucrose solution and 15 mg. $1^{-1}$ of $\mathrm{NaOCl}$ was best by giving good response on minimum flower wilting, dry weight and vase life.

\section{Recommendations}

$12 \%$ of sucrose solution and $15 \mathrm{mgl}^{-1}$ of $\mathrm{NaOCl}$ should be applied for prolonging vase life. Future research should be conducted to study higher concentration of sucrose and $\mathrm{NaOCl}$.

\section{Authors' contributions}

Conceived and designed the experiments: MOU Awan, N Khan \& M Ali, Performed the experiments: MOU Awan, Analyzed the data: JA Shah, A Ali, N Mehmood, I Ahmad \& AUR Khalil, Contributed reagents/ materials/ 
analysis tools: M Jounaid, Sohail, F Nawaz \& $\mathrm{R}$ Khan, Wrote the paper: $\mathrm{N}$ Khan, MOU Awan \& Z Ullah.

\section{References}

1. Singh BK, Rakesh ES, Yadav VPS \& Singh DK (2010). Adoption of commercial cut flower production technology in Meerut. Indian Res J Ext Edu 10(1): 50-53.

2. M, Ashfaq M \& Ali I (2013). Economics analysis of cut-flowers production in Punjab, Pakistan. Pak. J Agri Sci 50: 311-315.

3. Younis A, Riaz A, Qasim M \& Akhtar S (2002). Development and management of green spaces on Sumundri road, Faisalabad: A case study. Pakistan. Pak. J Agri Sci 39: 292-296.

4. Butt SJ (2003). A Review on prolonging the vase life of Roses. Pakistan Rose Annual published by National Rose society. pp:49-53

5. Farooq MU, Ahmad I \& Khan MA (2004). Storage and vase life of cut rose flowers as influenced by various packing materials. Int. J Agri Biol 6(2): 22-24.

6. Liao L, Lin Y, Huang K, Chen W, Cheng Y, Liao LJ, Lin YH, Huang KL, Chen WS \& Cheng YM (2008). Post-harvest life of cut rose flowers as affected by sodium hypochlorite and sucrose. Bot. Bulletin of Academia Sinica 4(41): 299303.

7. Ichimura K, Kawabata Y, Kishimoto M, Goto R \& Yamada K (2003). Shortage of soluble carbohydrates is largely responsible for short vase life of cut 'Sonia' rose flowers. J Japan soc of Hort Sci 72: 292-298.

8. Liao L, Lin Y, Huang K, Chen W \& Cheng Y (2000). Postharvest life of cut rose flowers as affected by silver sodium hypochlorite and sucrose. Bot Bull Acad Sin 41: 299-303.

9. Lorence R \& Heinrich JH (2003). Effect of changes in substrate salinity on the elongation of Rosa hybrida L. 'Kardinal' stems. Hort Sci 101: 103-119.

10. Doorn VG, Schurer K \& De Witte Y (1998). Role of endogenous bacteria in vascular blockage of cut rose flowers. $J$. Pl. Physiol 134: 375-381.

11. Ichimura K \& Kojima M (1999). Effects of temperature, hydroxyl quinoline sulphate and sucrose on the vase life of cut rose flower. Postharvest Biol \& Techn 15: 33-40.

12. Sobhani M (2000). Evaluation of different chemical treatments for increasing the vase life of Chrysanthemum cuts. Gilan University, Thesis of Master of Science.

13. Doorn VG, Schurer K \& De Witte Y (1997). Role of endogenous bacteria in vascular blockage of cut rose flowers. $J$ Pl Physiol 134: 375-381.

14. Hutchinsen MJ, Chebet DK \& Emongor VE (2005). Effect of ACCL, sucrose and silver thiosulfate, $\mathrm{NaOCl}$ on the water relation and post-harvest physiology of cut Tuberose flowers. African Crop Sci J 11(4): 279-287.

15. Elgimabi MN \& Ahmed OK (2009). Effects of Bactericides and SucrosePulsing on Vase Life of Rose Cut Flowers (Rosa hybirida). Bot Res Int 2(3): 164168.

16. Reddy BS, Gupta AK \& Singh K (1994). Physiological role of 8-hydroxyquinoline sulphate and sucrose in the post-harvest physiology of cut rose cv. Sylvia. In J. Prakash \& K. R. Bhandary (Eds.), Floriculture Technology, Trades and Trends (pp.496-502). Oxford \& IBH Publishing Co. Pvt. Ltd. Calcutta.

17. Williamson B, Tudzynski B, Tudzynski P \& Kan JAL (2007). Impact of supplement assimilation light on stem hydraulic conductivity of cut roses. Mol Plant Pathol 8:561-580.

18. Borochov A \& Mayak S (1984). The effect of simulated shipping conditions on subsequent bud opening of cut spray carnation flowers. Sci Hort 22: 173-180.

19. Chen WS (2001). Kinetin, gibberellic acid and sucrose affect vase life in Oncidiumspp. Acta Bot Gal-lica 148: 177-181. 